\title{
LEGAL ASPECTS OF SECURITY OF THE MILITARY INFRASTRUCTURE VERSUS ITS SECURITY EFFECTIVENESS
}

\author{
Ryszard Radziejewski, PhD \\ Military University of Technology, Warsaw
}

\begin{abstract}
The author has analysed legal legislatives that regulate security of the military infrastructure. Basing on it, he put forward the thesis that efficiency of operation of military administration in this range is unsuitable to contemporary threats of this infrastructure. And is also ineffective in protection of the infrastructure.
\end{abstract}

An army was associated and it still is associated with safety - due to the possession of weapon, having organized structures, and professional training. Army - it is also order and discipline. Is it really like that? Belief in these synonyms has been shaken after the first confrontations with the west armies - at the beginning, during common exercises within the framework of "Partnership for Peace" and next, during missions in Iraq and Afghanistan. These missions were called by politicians and staff officers, with high sense of humour, as "stabilizing" ones. They showed brutal reality - real enemy, with no sense of humour, but having the methods and means for fight different from ours used at military training grounds. This enemy has verified, in a brutal way, preparation of our soldiers for the fight.

Today, one can say that conclusions have been drawn - unfortunately only in preparation (training, equipment) of consecutive teams going for missions. These preparations have dominated not only training of the army in Poland but also moved away the problems which are also as important as safety of our soldiers during mission. One of these problems is safety of military (defence) infrastructure which includes "all stationary (in some special cases also movable) objects and instruments". They, according to their application, are used to provide the needs of armed forces, especially for command, living, training, and army transport ${ }^{1}$.

Transport of the army - not only the Polish army: "The basis to ensure credibility of enhancement Poland defence against threats by other NATO countries and also our participation in military NATO operation outside our territory is to achieve inter-compatibility (ability for common operation) by the Polish army and preparation of the infrastructure and the whole state organization for fulfilment of the Host

1 Słownik terminów z zakresu bezpieczeństwa narodowego. Akademia Obrony Narodowej, Warszawa 2002, wydanie czwarte, s. 49. 
Nation Support (HNS) mission². For sure, inter-compatibility is better achieved in Afghanistan than during common partnership exercises at training grounds, but we cannot forget that "Poland can have support of allied countries partners only if Poland will want and will be able to protect itself, if Poland will have its own possibilities of scaring away attacker"3.

First of all, the Polish army should defend at the Vistula River and thus, "The proportion between defence of own territory and expedition operations should be carefully considered" 4 . "To these people, who say that this what our soldiers would learn in Afghanistan they would not learn at our training grounds, one should quickly answer that what our soldiers would learn at our training grounds they would never learn in Afghanistan"5. However, "preparation of infrastructure and the whole national organisation" encompasses also key national infrastructure including also

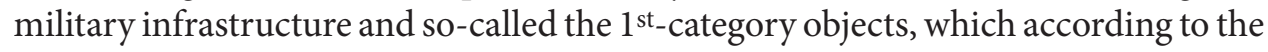
decree of the Cabinet of 24 June 2003 can be protected with the army participation" 6 (figure). No one remember about this (excluding small group of people, directly dealing with this problem) - or - as I think, politician and military decision makers even do not know that such obligation exist!

The problem of protection of objects subordinated to army should be considered in the category of "own" objects (military infrastructure) and the objects determined in the Cabinet's decree as especially important for safety and defence of the country. This problem (and also its scale) results from the infrastructure itself: "Huge number and spatial scale of critical infrastructure, determining national safety and simultaneously sensitive to military attack or terror acts, is great challenge in creation of national safety of the 21 st century"7.

This challenge is the greater because "Especially sensitive to terror acts are modern agglomerations with their industrial infrastructures and huge people concentration. Specificity of terror threat is that the terror acts can cause other types of threats. Assassination attack, besides direct effects such as casualities and material losses can cause fire and in case of application of some substances - chemical, radioactive, or bacteriological contamination. The attack on critical infrastructure causes the threat connected with breakdown of energetic, gaseous, or transport

2 Obrona narodowa w tworzeniu bezpieczeństwa III RP. Podręcznik dla studentek i studentów, red. R. Jakubczak, Dom Wydawniczy Bellona, Warszawa 2004, s. 135.

3 J. Nowak-Jeziorański, Polska wczoraj, dziś i jutro. Warszawa 1999, s. 246.

4 B. Pacek, Lekcja do odrobienia, „Polska Zbrojna” z 24 października 2010 r.

5 P. Makarewicz, Czy nasza armia obroni Polskę?, „Przegląd” z 14 listopada 2010 r.

6 Rozporządzenie Rady Ministrów z 24 czerwca 2003 r. w sprawie obiektów szczególnie ważnych dla bezpieczeństwa i obronności państwa oraz ich szczególnej ochrony, Dz.U. Nr 116 z 2003 r., poz. 1090.

7 Bezpieczeństwo narodowe Polski w XXI wieku. Wyzwania i strategie, red. R. Jakubczak, J. Flis, Bellona, Warszawa 2006, s. 100. 
networks" 8 . It is so-called cascade or dominoes effect - dangerous also for military infrastructure because it also depends on delivery of electrical energy, gas, or water. Moreover, each armed conflict (and also majority of terrorist attacks) starts from attacks on military infrastructure (key country's infrastructure)! So, the question about the state of its protection is very legitimate.

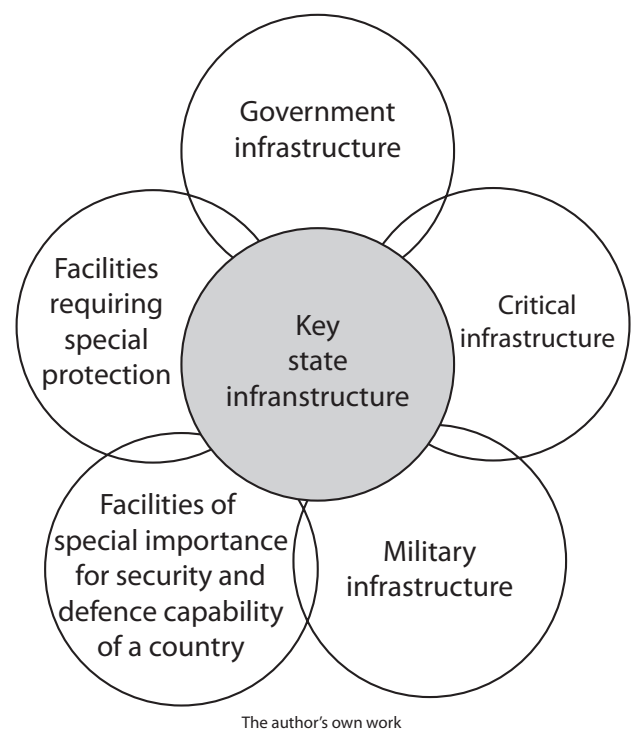

Figure. Key national infrastructure (own elaboration)

In the context of the conference title (Efficiency in relation to legality of national administration in safety and public order sphere) the author makes a thesis that efficiency of military administration activity in a sphere of legal regulations for military infrastructure protection is not adequate to contemporary threats and conditions in which operates the army today what causes that military infrastructure is protected in compliance with the law but ineffectively.

Efficiency means ,efficient action, operation of some device, efficient activity, efficient organization of some operations, activities"9. It is difficult to note this efficiency in a sphere of legal determinations what does not change the fact that military infrastructure is legally protected (legal - "consistent with obligatory law or having legal force"10). However, does legal mean efficient ("providing desirable results"11).

\footnotetext{
8 A. Najgebauer, R. Antkiewicz, M. Chmielewski, R. Kasprzyk, Zagrożenia terrorystyczne, (w:) A. Najgebauer (red.): Modele zagrożeń aglomeracji miejskiej wraz z systemem zarządzania kryzysowego na przykładzie miasta stołecznego Warszawy, Redakcja Wydawnictw WAT, Warszawa 2009, s. 585.

9 Słownik języka polskiego, Państwowe Wydawnictwo Naukowe, t. 3, Warszawa 1981, s. 304.

10 Stownik języka polskiego PWN, Wydawnictwo Naukowe PWN, Warszawa 2008, s. 394.

11 Stownik języka polskiego PWN, op. cit., s. 923.
} 
No, if badly made law is not adequate to real needs of determined social group or it does not regulate determined domain in adequate way to real needs.

The author justifies the assumed thesis on the basis of the analysis of:

- legal state of military infrastructure protection;

- effectiveness of its protection.

\section{Legal status of military infrastructure protection}

Basic legislatives, being the base of today protected military infrastructure, were formulated many years ago in other conditions of the army operation and just at the moment when they come into effect they were not adequate to reality. All the more, today, when the army is being still reduced and it gets more and more professional, these legislatives are not proper. What's more, they create precedents which are dangerous for military infrastructure safety as well as for the National Safety. National Safety is defined as "the highest value, national need and priority aim of the activity of the country, individuals, and social groups and simultaneously it is the process including various means that guarantee stable existence without disturbances and national development, i.e., protection and defence of the country as political institution and protection of individuals and the whole society, their property and natural environment against threats which significantly limit its functioning or strike the values submitted to special protection"12.

In structural (system) meaning, ,national safety it is the whole process of preparation and organisation of the country for continuous creation of national safety comprising the following basic elements:

- legal bases of safety;

- politics and strategy of national safety;

- civil and military organisation for national protection and defence;

- safety infrastructure;

- education for safety;

- alliances and international cooperation within the safety range"13.

Not without reason, legal safety aspects are mentioned at the first place, because as correctly notices W. Kitler, "Success, resulting in proper perception of national safety, its organizational and subject contents, depends on good knowledge of the law - determined by the law standards and principles" ${ }^{14}$. However, it is difficult to

12 J. Pawłowski, System kierowania bezpieczeństwem narodowym - teoria i praktyka, [w:] Wspótczesny wymiar bezpieczeństwa. Między teoria a praktyka, s. 56, [za:] W. Kitler, Rozważania nad istota bezpieczeństwa narodowego jako etap wstępny ustaleń dotyczących systemu bezpieczeństwa narodowego. Materiały eksperckie do prac w ramach SPBN, AON, Warszawa 2011.

${ }^{13}$ Bezpieczeństwo narodowe Polski w XXI wieku. Wyzwania i strategie, op. cit., s. 22.

14 W. Kitler, Prawo bezpieczeństwa narodowego w systemie prawa, „Zeszyty Naukowe Akademii Obrony Narodowej" nr 2/2011, s. 70. 
talk about proper perception of the law if the system of its creation in Poland is not adequate to social-political situation, to quickly changing military environment: "the law in Poland is created in a comprehensive wrong way, incoherently, accidentally, with lobbing influence (hazard casus) and as a result, the whole national executive from the ministry to the commune is plunged in chaos"15. It is also difficult to question this opinion, especially if it was told in public by Jan Rokita, formerly prominent politician and former head of the Cabinet Office.

How security should be properly perceived if the standards and principles made by the country are incoherent and are not clear? Especially, if we have consciousness that "Until now observed, the practice of management of the national security in Poland causes a lot of reservations. It is rather operational reaction to continuously appearing new conditions and needs. It becomes much more obvious that we should not still go blindfold and accidentally in the future (...). It cannot be only continuous repair of incessant "croaking» current reality. Such an initiative should be fully accepted and one can hope that the author of these words S. Koziej, already as a head of the National Security Office, main animator of the Strategic Review of National Security"16, "did not forget" about it and in the final report of the review (on the basis of which is to write "White Book of National Security"), the law regulations of security (including security infrastructure) will be adequate.

Perhaps, then, it will not be the situation in which "Minister Klich estimated that the whole management of national security in Poland needs modification. " However, from the existing law, it results that defence minister is responsible only for operation of the army and non military part of the defence system. Thus, the Strategic Defence Review (SDR) will not be outside these frames»"17. The Defence Minister is responsible for protection of his "own" objects but they are protected on the basis of the acts and regulations of other departments. Lack of coherence between departments, together with financial limitations, gives only formal protection of objects what does not mean an efficient one. There is over thousand objects and 350 of them are protected, in majority (52.5\%), by specialised armed security formations (SASF), $44.5 \%$ by Civil Guard Units (CGU), and only $3 \%$ by soldiers ${ }^{18}$.

SASF is, according to the act on protection of persons and property, an internal security service and entrepreneurs who obtained the licences for doing economic activity within the range of protection services of persons and property ${ }^{19}$. The obligatory condition to employ armed security formation of entrepreneur in military unit

15 J. Rokita, Prawo pierwszego tygodnia, „Newsweek” z 10-16 października $2011 \mathrm{r}$.

16 Zob. S. Koziej, Między piekłem a rajem. Szare bezpieczeństwo na progu XXI wieku, Wydawnictwo Adam Marszałek, Toruń 2008, s. 281.

17 A. Goławski, Bezkresne pasmo reform, „Polska Zbrojna” z 21 czerwca 2009 r.

18 K. Kowalczyk, Cenna ochrona, „Polska Zbrojna” z 16 stycznia 2011 r.

19 Ustawa o ochronie osób i mienia z 22 sierpnia 1997 r., Dz.U. Nr 114 z 1997 r., poz. 740. 
is "performance of adequate changes in the organizational structure of a military unit when structural security sub-unit is dis-formed or number of employees is reduced and the financial means for security services performance by this formation are ensured. Also the entrepreneur has to accept performance of security services after announcement of mobilisation state, martial law or during the war". Moreover "After announcement of mobilisation state, martial law or during the war, protection of terrain of organization units, objects and military devices can be performed by specialised armed security formations of entrepreneurs that are militarized according to the rules and in a mode determined in the decree of the Cabinet of the $21^{\text {st }}$ May 2002 on militarization of organizational units making tasks for the country protection and security"20.

Civil Guards Units (CGUs) are internal services for protection of organizational units of the Ministry of Defence, appointed for protection of their property and persons ${ }^{21}$. CGU is created, on a proposal from a commander of military unit, by adequate commander of a branch of the Armed Forces or the Commander of Warsaw Garrison.

The obligatory condition to form CGU in a military unit is to make changes in the unit's organizational structure and to allocate the money for CGU's guards. After announcement of mobilisation state, martial law or during the war, security performance from CGU is taken over by military sub-divisions of objects security and defence.

The army, despite security of its "own" objects participates also, as mentioned earlier, in preparation of security of the objects that are especially important for the country's safety and defence (among other there are industrial producing plants, repairing plants, and the plants storing weapons, military equipment, combat means, the stores of national reserves including bases and warehouses of fluid fuels, medicines, and sanitary products, the objects of organizational units subordinated to the Ministry of Defence or supervised by it, the objects of car, railway, and communications transport infrastructure as well as geodesy and cartography documentation centres, the objects of organizational units of the Intelligence Agency). There are the $1^{\text {st }}$ category objects, the special security of which is prepared and will be carried out with participation of the Armed Forces.

In compliance with the decree, the Defence Minister has the following tasks:

${ }^{20}$ Rozporządzenie ministra obrony narodowej z 25 stycznia 2006 r. zmieniające rozporządzenie w sprawie ochrony przez specjalistyczne uzbrojone formacje ochronne terenów komórek i jednostek organizacyjnych resortu obrony narodowej, Dz.U. Nr 19 z 2006 r., poz. 148.

${ }^{21}$ Rozporządzenie ministra obrony narodowej z 2 czerwca 1999 r. w sprawie wewnętrznych służb ochrony działających na terenach komórek i jednostek organizacyjnych resortu obrony narodowej, Dz.U. Nr 58 z 1999 r., poz. 619 z późn. zm. 
„1) precise determination, after taking an opinion from the minister of the interior, general requirements of preparation and performance of security of the $1^{\text {st }} \mathrm{ca}$ tegory objects;

2) elaboration of the plans of special security of the $1^{\text {st }}$ category objects, the special security of which is prepared and will be carried out with participation of the Armed Forces;

3) carrying records of the 1st category objects on the basis of the register mentioned in $₫ 4$, section 1 ;

4) determination, after taking an opinion of the organs mentioned in $₫ 4$, section 2 , of precise method of assurance of the needs for personal reserves, weapons, military equipment, release from obligation of serving military service and services for defence, indispensable for special protection of objects;

5) taking decision on participation of the Polish Armed Forces in special protection of objects and determination of the scope and way of this participation after taking an opinion from the organs mentioned in $₫ 4$, section 2 ;

6) organisation and carrying, together with the minister of the interior, special training for persons organising performance of the tasks within the range of special protection of the $1^{\text {st }}$ category objects".

As one can see, a number of the tasks predicted for the army is very high. Not only complicated organizational operations are needed but also significant material and weapon means can be ensured. If we multiply it by a number of objects, vastness of this task can be seen. Especially, that "Special protection of objects consists in its preparation and carrying. (...)

3. Performance of special protection of objects includes in particular:

1) direct physical security of objects and their technical protection;

2) other activities, aimed at object protection, resulting from the object specificity and type of threats affecting it functioning;

3) undertakings performed within the frame of alarming and communication systems and exchange of the information on threats

4) defence activities, including especially engineering extension of terrain, outside and inside the protected object, a fire system of firearms, common anti-aircraft defence, and protection against contaminations.

4. Special protection of objects is prepared by organs, institutions, formations, entrepreneurs or organisational units in which these objects are situated.

5. Special protection of objects is performed by military units, specially created for this purpose on the basis on separate regulations.

6. Special protection of objects is prepared and carried out with participation of the Polish Armed Forces, the Police, National Fire Brigade and formations of civil defence with reservation of $\S 4$, section 3 , point $8, \S 7$, section 2 , point 5 , and section 3 , point 4 . 


\section{What is the problem?}

At the first sight, it seems that everything is all right: military objects during peace are protected by SASF and CGU. After announcement of mobilisation state, martial law or during the war, CGU are militarized and still protect the objects ${ }^{22}$. Also other specialised armed security formations of entrepreneurs can be militarised. Instead of CGU protection is made by military sub-divisions of objects security and defence.

„Special protection of the 1st category objects are performed in the conditions of external threats of national security and during the war" 23 by specially created for it, on the basis of separate regulations, military units ( $\$ 5.5$ of the decree). Special protection of objects is prepared and carried out with participation of the Polish Armed Forces, the Police, National Fire Brigade and formations of civil defence with reservation of $\$ 4$, section 3 , point $8, \S 7$, section 2 , point 5 , and section 3 , point 4 ( $\$ 5.6$ of the decree).

The first question arises - who protects the $1^{\text {st }}$ category objects during peace? If we compare these objects with the list of objects, undergoing obligatory protection, on the basis of the act of persons and property protection (art. 5.2) ${ }^{24}$ and if we take into account a relation in the decree to protection planes $(, \$ 8$. For the tasks connected with preparation of special protection of objects, records and planes of these objects protection, elaborated in compliance with the regulations of the act of 22 August 1997 on protection of persons and property «...»"), the answer can be the only one - by commercial security agencies! But, how can they realize the regulation on "defence activities including especially engineering extension of terrain, outside and inside the protected object, a fire system of firearms, common anti-aircraft defence and protection against contaminations", if such activities are made by military sub-divisions?

Neglecting the question what for the legislative organ created a new category of objects, this organ confirmed itself: "Direct physical protection of the $1^{\text {st }}$ category objects is organized on the basis of:

1) internal security services, which have, during external threat of national security and during the war, mobilisation-organisation allocations or workers mobilisation allocations (it concerns security workers of civil guard divisions);

\footnotetext{
22 Rozporządzenie ministra obrony narodowej z 25 stycznia 2006 r. zmieniające rozporządzenie w sprawie ochrony przez specjalistyczne uzbrojone formacje ochronne terenów komórek i jednostek organizacyjnych resortu obrony narodowej, op. cit., $\$ 4$.

${ }^{23}$ Wytyczne ministra obrony narodowej z 20 grudnia 2004 r. w sprawie ogólnych wymagań przygotowania i prowadzenia szczególnej ochrony obiektów kategorii I, wydanie drugie, Warszawa 2005, Szt. OT Wewn. 1/2005, s. 7.

24 Ustawa o ochronie osób i mienia z 22 sierpnia 1997 r., op. cit.
} 
2) specialised armed security formation of entrepreneurs protecting the 1st category objects, which are militarised in the conditions of external threat of the country safety and during the war;

3) newly formed sub-divisions for security and defence of the objects of the Polish Armed Forces, the Police, National Fire Brigade, or civil defence formation ${ }^{25}$.

The militarised units, mentioned in the decree, are probably commercial agencies of persons and property protection, including specialised armed security formations of entrepreneurs protecting the $1^{\text {st }}$ category objects, which in compliance with the Cabinet decree on militarisation of organisational units, performing tasks for country's defence and safety - will protect the objects of special significance for the country safety and defence ${ }^{26}$. The author does not know the case when any of these firms has been subjected to the procedures predicted in the decree.

The exceptions are SASF which protect military objects. The condition to take part in a tender is to agree for their mobilization. In practice, it is only formal requirement. It is difficult to imagine mobilisation assignments for security workers in a situation of high fluctuation in their employment and the fact that, as a rule, they are employed simultaneously in several firms. How can be made mobilisation of security agency which protects military object and also the objects qualified as the $1^{\text {st }}$ category ones?

According to the Defence Minister's decree of 2nd June 1999, after mobilisation announcement, martial law introduction, or during the war, protection of military objects take from CGU - military and defence sub-divisions of objects security. However, in compliance with guidelines of the National Defence Minister of 20 December 2004, the workers of security divisions of civil guard obtain mobilization assignments what for? Neglecting the question - can be decree regulations (as well as regulations of Defence Strategy of the Republic of Poland ${ }^{27}$ ) substituted by guidelines? - who finally is to protect these objects? (Newly formed sub-divisions for security and defence of the objects of the Polish Armed Forces, the Police, National Fire Brigade, or civil defence formations?). Who should form these sub-divisions? What forces are in the Police which have to protect $2^{\text {nd }}$ category objects? Civil defence formations - there are no such formations!

${ }^{25}$ Wytyczne ministra obrony narodowej z 20 grudnia 2004 r. w sprawie ogólnych wymagań przygotowania i prowadzenia szczególnej ochrony obiektów kategorii I, op. cit., s. 7.

$26 \$$ 3.7. rozporządzenia Rady Ministrów z 24 listopada 2009 r. w sprawie militaryzacji jednostek organizacyjnych wykonujących zadania na rzecz obronności lub bezpieczeństwa państwa, Dz.U. z 11 grudnia $2009 \mathrm{r}$.

27 „Ochrona obiektów szczególnie ważnych dla bezpieczeństwa i obronności państwa prowadzona jest przez jednostki zmilitaryzowane przeznaczone do realizacji zadań ochronnych samodzielnie bądź z udziałem Sił Zbrojnych RP, Policji, Państwowej Straży Pożarnej i formacji obrony cywilnej”, STRATEGIA OBRONNOŚCI RZECZYPOSPOLITEJ POLSKIEJ. Strategia sektorowa do Strategii Bezpieczeństwa Narodowego Rzeczypospolitej Polskiej, 2009 r., art. 133. 
Only these doubts and question marks (there are a lot of them) confirmed the thesis that efficiency of military administration in a range of legislatives regulating security of military infrastructure is questionable.

\section{Effectiveness of military infrastructure protection}

The thesis of questionable efficiency of military administration is confirmed also by the analysis of effectiveness of protection performed by SASF and CGU. How these formations protect the objects belonging to the Ministry of Defence? The protection is very poor - according to the author of the article published in "Rzeczpospolita". „Elitist special unit "GROM" - terrain of its base was entered through a fence by several men. They were soldiers from the Control Department of the Ministry of Defence. No one stopped them. The presence of intruders was detected by electronic monitoring system. Similar cases were in the Special Division of Military Police in Mińsk Mazowiecki and other military units in the country"28. How do the journalists know it? From ... a secret report of the control which was partly published in "Rz"! Such situations should not occur because it is not fiction scenario in which the men from the control team could be replaced by terrorists. We take part in the World war with terrorism and we take part in Afghanistan war (earlier in Iraq). Poland is indicated in numerous statements of the heads of various terrorist organizations as potential target of the attack. These statements should not be disregarded: "After the $11^{\text {th }}$ September, the terrorists proved that they can hit in any place of the World and each country can be threatened. Victims of these attacks can be both superpowers as well as small and neutral countries"29.

Despite the attacks of "foreign" terrorists we cannot eliminate the activities of native imitators, who can get, e.g., chemical weapon, or the activities of criminal groups that want to steal weapon or explosives from military stores. There are the most real threats during peace but during military actions these objects would be attacked, as the first ones, by air forces or sabotage-recognition groups. Thus, the question" what is effectiveness of protection performed by SASF and CGU ? is legitimate. For answer to this question, one should know in which conditions operate commercial security agency (including SASF). In everyday life, we do not realise that the commercial branch of property protection is estimated for about 200 thousand people (nearly the number of soldiers and policemen together!) and they protect about 4 thousand (estimated data) of the objects qualified, in the act on protection of persons and property (regulating activity of commercial security agencies, including SASF), as the objects requiring

${ }^{28}$ E. Żemła, Wojsko fatalnie chronione, „Rzeczpospolita” z 25 marca $2011 \mathrm{r}$.

${ }^{29}$ I. Jankowska, Wspótczesny terroryzm - największe zagrożenie bezpieczeństwa człowieka, [w:] Zarządzanie bezpieczeństwem w Unii Europejskiej wobec globalnych zagrożeń, Wydawnictwo Wyższej Szkoły Gospodarki Euroregionalnej, Józefów 2008, s. 90. 
special protection (including the mentioned objects, especially important for safety and defence of the country) and 840 objects of critical infrastructure).

When the act came into effect in 1997, the threat for the objects undergoing obligatory protection was estimated in different way: "Only several years ago, embassies, government buildings and ministry buildings were considered as relatively safe ones and their protection was limited to protection against noisy demonstrants. Also, for such objects as military bases, airports, and refineries protection, the basis of a system of district (peripheral) security were high fancies and wire entanglements and guarded access to the protected area by an armed security guard" 30 . Today, unfortunately, the character and essence of threats changed but preparation of workers of commercial security agencies to counteract them did not change.

Security agencies were, and still are, focused on the objects undergoing obligatory protection because they have there the "reliable" money and competition about the money is serious: "Agencies strongly compete during tenders on the protection of government offices protection (including military infrastructure - author's note) (...). Recently, systematically have won dumping offers with 7-8 Polish zloty ( 2 Euros) together with bonuses for one-hour work of security worker (it should be at least 17.50 Polish zloty net ( 4 Euros), the author's note- www.piooim.pl) irritates Mr Wagner" 31.

Not only Mr Wagner - the Chairman of the Polish Chamber of People and Property Protection should irritate but, first of all, all the people responsive for these objects protection because they know that this money cannot ensure effective protection. What can they do if, the most frequently, a price is the decisive factor? Merciless fight about the client has caused the fact that security agencies pretend that they protect and the firms being protected pretend that they pay for such protection.

In such a situation, the question about security effectiveness is aimless, especially if training of security workers finishes after receiving a licence, although there were and are problems with its receiving: "The most problematic are practical tasks. It seems that for the firms conducting the courses, self-defence, intervention techniques, and shooting are of too little importance. The result was that about $90 \%$ of course attendances passed theoretical exam and only $50 \%$ of them a practical one" 32 . Not better was 10 years later: "As a result, from 22 to 24 September 2009, at the Headquarters of Capital Police, 112 persons entered for an examination and only 25 people have passed the exam, what constitutes about $22 \%$ of all attendances" 33 .

30 B. Kędzia, Zabezpieczenia $w$ dobie terroryzmu, „Zabezpieczenia” nr 3/2007.

${ }^{31}$ R. Omachel, W. Surmacz, Zarobić na strachu, „Newsweek” z 9 sierpnia 2009 r.

32 R. Radziejewski, Pierwszy w „Stołecznej”, „BOS. Bezpieczeństwo-Ochrona-Systemy” nr 4/1999.

${ }^{33}$ D. Godlewska, A. Korus, Egzamin dla osób ubiegających się o licencję pracownika ochrony fizycznej okiem Polskiego Związku Pracodawców OCHRONA, „Ochrona Mienia i Informacji” nr 6/2009. 
Thus, for 200 thousand of security workers "Only 20\% of security service workers have adequate qualification said Janusz Raczyński, representative of the International Bodyguard Association in Poland" 34 . If de-regulative proposals of the Justice Minister Jarosław Gowin will take into effect and the licences will not be obligatory, the effectiveness of protection will be even lower!

What is effectiveness of protection performed by CGU? According to the information from "Rzeczpospolita", "for the places where the army is protected by civil workers, the control showed better results than for the places where the agencies were employed" 35 . The control results were better because the most frequently CGU employs soldiers who are better prepared (physically and essentially) for such type of activities. It does not mean that both CGU and SASF are ready to face up to contemporary threats! It is because, generally, the task of these formations is to ensure: protection of terrains of organizational units, objects and military equipment and protection against stealing, destruction or damage of the entrusted military poverty as well as control of entitlement for entry and stay on the terrain of organizational units (CGU)" or "prevention crimes and offences against property and also counteraction the damage resulting from these events as well as exclusion of entry of non entitled persons (SASF)". Neither aim of activity nor preparation of workers (exactly lack of their preparation) and possession of firearms are enough for efficient counteraction against terrorists or against well equipped and trained soldiers of sabotage-reconnaissance groups.

\section{Conclusions}

If SASF and CGU do not meet requirements of effective protection, maybe we should return to the situation when the army protects itself? This is when soldiers were the guards. No - because the cost of "civil" guard is much lower. It results from a simulation that "the cost of only military guard, at all protected military objects, will be about 650 million Polish zloty, ( 160 million Euros), the cost with employed CGU and SASF will be over 470 million Polish zloty ( $\sim 120$ million Euros). What's more, in the second variant, we would have perfect solution for the Army because theoretically all soldiers would be released from the guard and they would train and made other duty tasks" 36 . It should be like that. However, the money could not be decisive for effectiveness of objects protection. The damage and destruction of objects not only reduce the country's defensive system but it can be a reason of terrorist threats (e.g., after stealing combat toxic chemicals) or a catastrophe (blowing up ammunition stores or explosives)

\footnotetext{
34 R. Omachel, W. Surmacz, Zarobić na strachu, op. cit.

35 E. Żemła, Wojsko fatalnie chronione, op. cit.

36 K. Kowalczyk, Cenna ochrona, op. cit.
} 
Thus, the following undertakings should be done:

- review of obligatory legislatives in the range of protection of military infrastructure (and also other elements of key infrastructure of the country). One act should be issued which will regulate protection in all states of the country threats - protection should be the same during peace and war. The same protection - in the meaning of its effectiveness and readiness for immediate repulsing of every attack, because the time from the obtained information on the possibility of attack of the determined object to the attack start can be minimal or the attack can be even immediate. So, all activities connected with "mobilisation" are pointless. However, for the system of military objects protection they are important because contemporary armed conflicts are different than these which occurred some years ago and threats against the country safety, first of all, are connected with asymmetrical threats;

- precise selection of objects requiring reliable protection performed by specialised protection units, adequately equipped and trained for the tasks connected not only with their protection but also with their defence.

Thus, on the basis of this short analysis, efficiency of operation of government and military administration in the range of protection of military infrastructure objects should be estimated as critical one. What's more, the author gives the thesis that the highest threats for protection of military infrastructure objects is passiveness of the persons of national administration and the persons taking decision about military legislatives as well as their pretending that the present legislatives ensure effective protection of these objects.

\section{REFERENCES}

1. GoŁawski A., Bezkresne pasmo reform, „Polska Zbrojna” z 21 czerwca 2009 r.

2. Godlewska D., Korus A., Egzamin dla osób ubiegających się o licencję pracownika ochrony fizycznej okiem Polskiego Związku Pracodawców OCHRONA, „Ochrona Mienia i Informacji” nr 6/2009.

3. JakubCzak R. (red.), Obrona narodowa w tworzeniu bezpieczeństwa III RP. Podręcznik dla studentek i studentów, Dom Wydawniczy Bellona, Warszawa 2004.

4. Jакuвсzак R., Flis J. (red.), Bezpieczeństwo narodowe Polski w XXI wieku. Wyzwania i strategie, Bellona, Warszawa 2006.

5. KęDzia B., Zabezpieczenia $w$ dobie terroryzmu, „Zabezpieczenia” nr 3/2007.

6. Kitler W., Prawo bezpieczeństwa narodowego w systemie prawa, „Zeszyty Naukowe Akademii Obrony Narodowej" nr 2/2011.

7. Kitler W., Rozważania nad istota bezpieczeństwa narodowego jako etap wstępny ustaleń dotyczacych systemu bezpieczeństwa narodowego, materiały eksperckie do prac w ramach SPBN, AON, Warszawa 2011. 
8. Kowalczyk K., Cenna ochrona, „Polska Zbrojna” z 16 stycznia $2011 \mathrm{r}$.

9. KozIEJ S., Między piekłem a rajem. Szare bezpieczeństwo na progu XXI wieku, Wydawnictwo Adam Marszałek, Toruń 2008.

10. Makarewicz P., Czy nasza armia obroni Polskę?, „Przegląd” z 14 listopada 2010 r.

11. Najgebauer A., Modele zagrożeń aglomeracji miejskiej wraz z systemem zarzadzania kryzysowego na przykładzie miasta stołecznego Warszawy, Redakcja Wydawnictw WAT, Warszawa 2009.

12. Nowak-Jeziorański J., Polska wczoraj, dziś i jutro, Warszawa 1999.

13. Omachel R., Surmacz W., Zarobić na strachu, „Newsweek” z 9 sierpnia 2009 r.

14. PACEк B., Lekcja do odrobienia, „Polska Zbrojna” z 24 października 2010 r.

15. Radziejewski R., Pierwszy w „Stołecznej”, „BOS. Bezpieczeństwo-Ochrona-Systemy” nr 4/1999.

16. Rokita J., Prawo pierwszego tygodnia. „Newsweek” z 10-16 października $2011 \mathrm{r}$.

17. Słownik języka polskiego, Państwowe Wydawnictwo Naukowe, t. 3, Warszawa 1981.

18. Słownik języka polskiego PWN, Wydawnictwo Naukowe PWN, Warszawa 2008.

19. Słownik terminów z zakresu bezpieczeństwa narodowego, Akademia Obrony Narodowej, Warszawa 2002, wydanie czwarte.

20. Zarządzanie bezpieczeństwem w Unii Europejskiej wobec globalnych zagrożeń, Wydawnictwo Wyższej Szkoły Gospodarki Euroregionalnej, Józefów 2008.

21. ŻEMŁA E., Wojsko fatalnie chronione, „Rzeczpospolita” z 25 marca 2011 r.

\section{LIST OF LEGISLATIVES}

1. The act of persons and property protection of 22 August 1997, „Official Gazette Announcing Current Legislation" No. 114 of 1997, point 740.

2. The decree of the National Defence Minister of 2 June 1999, on internal security services operating on terrains of organisational units of national defence department, „Official Gazette Announcing Current Legislation” No. 58 of 1999, point 619 with later changes.

3. The decree of the Cabinet of 24 June 2003 on objects especially important for security and defence of the country and their special protection, „Official Gazette Announcing Current Legislation" No. 116 of 2003, point 1090.

4. Directions of the National Defence Minister of 20 December 2004 on general requirements for preparation and performance of special protection of the $1^{\text {st }}$ category objects, $2^{\text {nd }}$ issue, Warsaw, 2005, 1/2005, page 7 .

5. The decree of the National Defence Minister of 25 January 2006 changing the decree on protection performed by specialised armed security formations on terrains of organisational units of national defence department, „Official Gazette Announcing Current Legislation" No. 19 of 2006, point 148.

6. STRATEGY OF DEFENCE OF THE REPUBLIC OF POLAND, Sector Strategy for Strategy of Defence of the Republic of Poland, 2009. 
7. The decree of the Cabinet of 4 November 2009 on militarization of organisational units performing tasks for defensive system or safety of the country, „Official Gazette Announcing Current Legislation" of $11^{\text {th }}$ December 2009.

8. Decree No. 4 of the President of the Republic of Poland of 24 November 2010, www. bbn.gov.pl, last issue 9.05.2012.

\section{Prawne aspekty ochrony infrastruktury militarnej a skuteczność jej ochrony}

Streszczenie: Autor poddał analizie akty prawne regulujące ochronę infrastruktury militarnej i na tej podstawie wysunął tezę, iż sprawność działania administracji wojskowej w tym obszarze jest nieadekwatna do współczesnych zagrożeń tej infrastruktury, podobnie jak skuteczność jej ochrony. 